\title{
Pharyngeal Airway Space in Subjects with Class II and Class III Facial Deformities
}

\author{
Espacio de la Vía Aérea Faríngea en Sujetos con Deformidad Facial Clase II y Clase III
}

\author{
Sergio Olate ${ }^{*, *, * * * *} ;$ Mario Cantín ${ }^{*, * * * * *}$; Bélgica Vásquez ${ }^{* * * *, * * * * * * *}$; \\ Mariano del Sol ${ }^{* * * * *}$; Miguel Henriquez-Alarcón ${ }^{* * * * * * *}$ \& Márcio de Moraes ${ }^{* * * *}$
}

OLATE, S.; CANTIN, M.; VASQUEZ, B.; DEL SOL, M.; HENRIQUEZ-ALARCÓN, M. \& DE MORAES, M. Pharyngeal airway space in subjects with class II and class III facial deformities. Int. J. Morphol., 32(4):1271-1276, 2014.

SUMMARY: Facial deformities are related to morphological differences and the mandible position shows differences in maxillomandible relation. The aim of this research was to compare the pharyngeal airway space (PAS) in subjects with class II and class III facial deformities We included 28 adult subjects with skeletal characteristics associated to class II or class III according to the SNA angle and dental overjet; subjects with facial asymmetry and other facial deformities and subjects with facial trauma or facial surgery history were excluded. Cone beam computed tomography was realized (CBCT) to asses the nasopharynx, oropharynx, hypopharynx, as well as the distance measured between the mandible genial spine and hyoid bone; data analysis were realized by descriptive analysis and statistical analysis using t test with 0.05 to show statistical differences. Class II subjects presented minor values in all of the measurements; in the oropharynx and the hypopharynx we observed the most important differences, with nasopharynx showing statistically significant differences $(\mathrm{p}<0.05)$. In conclusion class II subjects presented a minor pharyngeal airway space and it is suggested that this information should be used in the diagnosis process and prior to surgical treatment.

KEY WORDS: Facial deformity; Pharyngeal airway; Obstructive sleep apnea.

\section{INTRODUCTION}

Facial deformities (FD) have been associated to skeletal conditions with complications in hard and soft tissue showing a common characterization in functional, aesthetic and facial morphology. In some research it has been demonstrated that no important differences are observed in soft tissue when facial class II and class III are compared. In this study we observed some differences in the lower lip position related to the retraced position of the mandible (Olate et al., 2014); furthermore, it has been confirmed that mandible condyle morphology in TMJ (temporo mandibular joint) shows differences when comparing subjects with facial class II or facial class III (Muñoz et al., 2014a, 2014b); this can justify differences in TMJ response after skeletal surgery by physiopathology of the TMJ (Saccucci et al., 2012).

Facial morphology differences can be related to mandible position (Olate et al., 2013). Condyle/fossa relation in TMJ and hyoid bone position are modified because the jaw, tongue base, hyoid bone, and pharyngeal walls are intimately connected by muscles and tendons. The tongue with its muscles and ligaments is related to the hyoid bone and mandible. When the mandible is posteriorly repositioned, the tongue assumes a more posterior position, narrowing the pharyngeal airway space (PAS) (Saitoh, 2004; Kitagawara, 2008; Machado \& Crespo, 2012).

The airway space presents a frequent modification with orthognathic surgery (Hong et al., 2011) and the management in obstructive sleep apnea (OSA) has been confirmed as an efficient and good cost / effective technique. OSA is characterized by repetitive collapse of the upper airway, commonly defined as the soft tissue region bound by the nasopharynx superiorly, the epiglottis inferiorly, the maxillomandibular complex anteriorly and the spinal column

\footnotetext{
* Division of Oral and Maxillofacial Surgery, CIMA Research group \& CEMYQ, Faculty of Dentistry, Universidad de La Frontera, Temuco, Chile.

** Center for Biomedical Research, Universidad Autónoma de Chile, Temuco, Chile.

*** Division of Oral and Maxillofacial Surgery, State University of Campinas, Piracicaba, Brazil.

**** PhD Program in Morphology Sciences, Medical School, Universidad de La Frontera, Temuco, Chile.

***** Universidad de Tarapacá, Arica, Chile.

****** Department of Medical Specialties, Division of Otorhinolaryngology, Universidad de La Frontera, Temuco, Chile.
} 
posteriorly. Collapse of the upper airway decreases its intra-luminal diameter and increases airway resistance, in accordance with Pouiseille's Law(Susarla et al., 2010).

Among patients without OSA, there is a relative concordance between the size of the skeletal airway enclosure (maxillomandibular complex and spinal column) and the soft tissue airway (Watanabe et al., 2002). In patients with OSA, a narrow airway can result from excessive soft tissue on a normal skeleton or from normal amounts of soft tissue on a deficient skeleton (White, 2005). Considering this information, obesity is a risk factor for excessive soft tissue into the PAS (White). The aim of this research is to compare the PAS in class II or class III facial deformities in subjects without obesity.

\section{MATERIAL AND METHOD}

An imaging study was carried out in subjects with facial deformity class II and III and orthognathic surgery indications. All the subjects signed an informed consent to participate in this study. Inclusion criteria for class II and class III patient was no obesity, obtained follow the mass corporal index, OMS criteria (http:// apps.who.int/ bmi/index.jsp?introPage=intro_3.html). For class II subjects included an SNB angle less than $78^{\circ}$ and an overjet greater than $3 \mathrm{~mm}$; inclusion criteria for class III subjects were a SNA angle less than $80^{\circ}$ and a negative overjet considered from $-2 \mathrm{~mm}$. Subjects with other skeletal anomalies, along with the class II or class III alteration, such as anterior open bite, facial asymmetries and vertical alterations comprising short and long face syndromes were excluded from the study. Subjects having experienced previous facial surgeries, fractures or pathologies requiring surgical resolution were also excluded.

The subjects underwent a clinical examination prior to the taking of records to define the conditions of the disease. Subsequently cone beam computerized tomography (CBCT) imaging was used, where maximum intercuspidation was maintained in a stable position. The PlanMeca ${ }^{\circledR}$ (Korea) unit was used for this.

The image was processed using the software

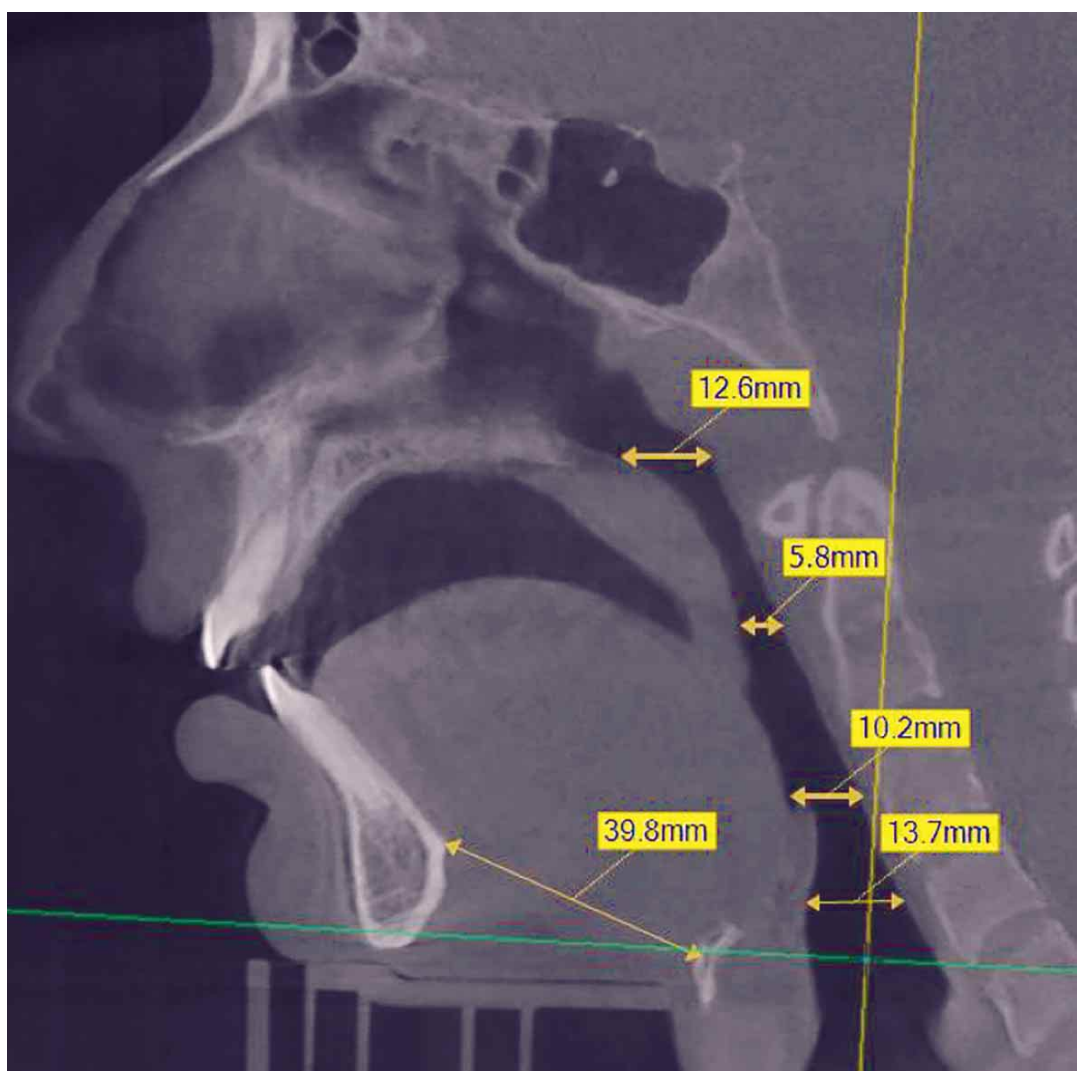

Fig. 1. Measurement in lateral image from the Cone Beam Computed Tomography study in FCII group. 
Simplant O\&O (for Intel X86 Platform V3.0.0.59, 2013 Materialise Dental n.v., Belgium), where the lateral x-ray image was extracted and contrast and brightness were adjusted to obtain the best image. The image was then magnified $4 \mathrm{X}$ to take the linear measurements, taking care to ensure that all measurements were parallel to one another. The cephalometric analysis of ArnettGunson FAB surgery was used to evaluate the PAS, landmarks used in this study are shown in Figure 1. The following linear items were measured (Fig. 1):

1. Nasopharynx: corresponds to a linear measurement between Arnett-Gunson (A/G) anterior PAS at the deepest point of the jaw (A) and $\mathrm{A} / \mathrm{G}$ posterior PAS at A.

2. Oropharynx: corresponds to a linear measurement between $\mathrm{A} / \mathrm{G}$ anterior PAS at the maxillary central incisor $(\mathrm{Mx} 1)$ and $\mathrm{A} / \mathrm{G}$ posterior PAS at Mx1.

3. Hypopharynx: corresponds to a linear measurement between $\mathrm{A} / \mathrm{G}$ anterior PAS at the most concave point in the anterior region of the symphysis (B) and $\mathrm{A} / \mathrm{G}$ posterior PAS at $\mathrm{B}$

In addition the lineal distance between the mandible geni spine and the hyoid bone was incorporated. To determine the measurement error and intraexaminer calibration, measurements were performed by a single examiner in duplicate, with a 1month interval between measurements. Reproducibility was estimated by an intraclass correlation coefficient. The data were analyzed descriptively and $\mathrm{T}$ test analysis with a significance level of 5\% was used for comparison.

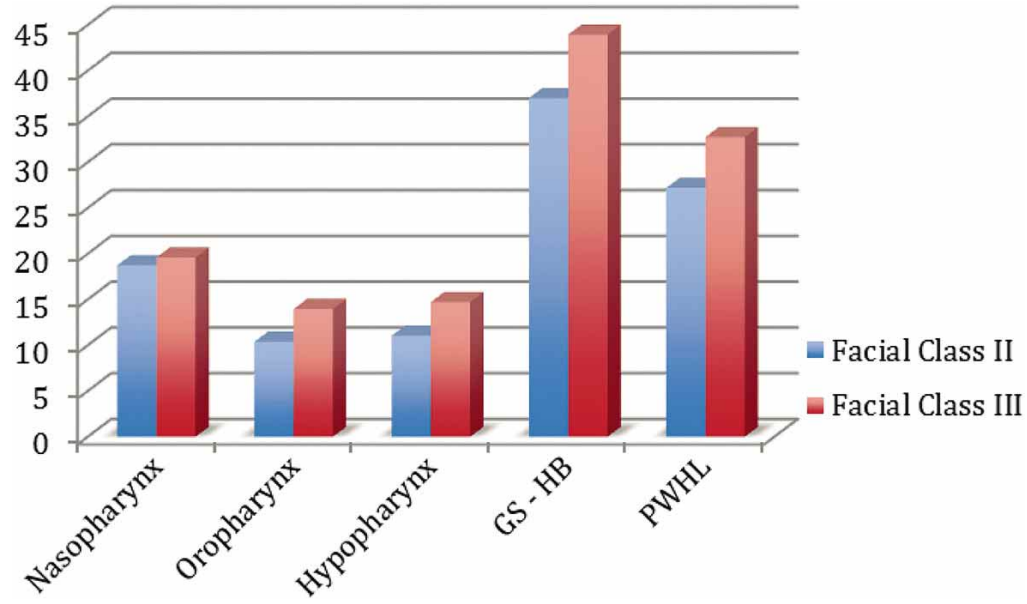

Fig. 2. Comparison between Facial Class II and Facial Class III in 28 subjects evaluated by computed tomography.

\section{RESULTS}

Twenty eight (28) subjects, 14 with class III and 14 with class II facial anomalies were analyzed. In the class II group, six subjects were female and 8 were male; in the class III group, nine were male and five were female. The average age of class II subjects was 19.6 years and of class III subjects 18.3 years.

Clear differences were observed between the groups. All the measurement showed a FCII with minor value than FCIII; the distance between the mandible geni spine and the hyoid bone in the FCIII group was almost $7 \mathrm{~mm}$ bigger than FCII group. This fact was statistically related to the PAS ( $\mathrm{p}=0.009)$. The nasopharyn $\mathrm{x}$ area shows minor differences $(0.88$ $\mathrm{mm}$ ) and no statistical difference was observed between the FCII and FCIII group in this area (Table I, Fig. 2).

The oropharynx and hypopharynx showed important differences where the FCIII group presented $3.59 \mathrm{~mm}$ and $3.67 \mathrm{~mm}$ over the FCII group. This measurement showed statistical positive relations $(\mathrm{p}=0.001)$ to facial class and was clearly related to the GS-HB distance. The PAS width in the hyoid bone level (coronal view) was $27.18 \mathrm{~mm}$ in the FCII group and $32.75 \mathrm{~mm}$ in the FCIII group, and this fact related to other measurement of the PAS in the sagittal view.

Table I. Relationship and differences observed in the PAW of Facial Class II and Facial Class III subjects.

\begin{tabular}{|c|c|c|c|c|c|}
\hline \multirow{2}{*}{ Group } & \multicolumn{2}{|c|}{ Facial Class II (FCII) } & \multicolumn{2}{|c|}{ Facial Class III (FCIII) } & \multirow{2}{*}{$\begin{array}{c}\text { Differences FCII-FCIII } \\
X(\mathrm{~mm})\end{array}$} \\
\hline & $X(\mathrm{~mm})$ & $S D(\mathrm{~mm})$ & $X(\mathrm{~mm})$ & $S D(\mathrm{~mm})$ & \\
\hline Nasopharynx & 18.71 & 3.75 & 19.59 & 2.66 & 0.88 \\
\hline Oropharynx & 10.37 & 3.69 & 13.96 & 4.28 & 3.59 \\
\hline Hypopharynx & 11.05 & 3.15 & 14.72 & 4.01 & 3.67 \\
\hline GS-HB & 37.01 & 4.18 & 43.94 & 4.47 & 6.93 \\
\hline PAS width Hyoid bone & 27.18 & 8.82 & 32.75 & 4.86 & 5.57 \\
\hline
\end{tabular}

GS= Mandible geni spine; $\mathrm{HB}=$ Hyoid bone; $\mathrm{PAS}=$ Pharynx airway space; $\mathrm{X}=$ average; $\mathrm{SD}=$ standard deviation 


\section{DISCUSSION}

Since the airway is $3 \mathrm{D}$ hard space surrounded by soft tissues, 3D image analysis is required if the most accurate information is to be obtained (Lenza et al., 2010). Lenza et al. insisted that the upper airway cannot accurately be represented by single linear measurements performed on cephalograms and that total volume alone cannot depict airway morphology. The present study shows a comparison between two different groups with differences in skeletal pathology and mandible position, and our results are an approximation to the PAS study in face skeletal pathology.

OSA is common in patients with heart failure, and may worsen prognosis by increasing sympathetic nervous system activity, raising blood pressure and triggering myocardial ischemia and arrhythmias (Bradley \& Floras, 2003). Obstructive apneas expose the cardiovascular system to intermittent hypoxia and sympathetic activation, and in addition, generate exaggerated negative intrathoracic pressure, which increases left ventricular wall tension and lowers stroke volume (Tkacova et al., 1998).

OSA is seen in children, young women, and asthenic individuals. A large number of patient populations at high risk for OSA have been identified. Mahowald et al. (1991) showed serial predisposing factors for OSA as 1) craniofacial, 2) neurological and neuromuscular, 3) iatrogenic and 4) syndrome / others presented a morphological situation of the mandible as an important matter. OSA treatment has been modified in agreed with Powell and Riley protocol (Powell et al., 1991) with a philosophy funded in 1) treatment to cure, 2) logically direct management, 3) full patient disclosure of options and risks, 4) stage surgical management and 5) follow-up all treatment.

Upper airway configuration as been explored in some research, however it is not possible to define what measurement value is related to respiratory deficiency, snoring or OSA (Susarla et al.). FCII group show a minor value in PAS than FCIII group, determining a risk factor for OSA (Mahawald et al.). However, in FCIII patients, it is common to take a surgical plan with mandible recue surgery with a resultant minor PAS in the postoperative time (Pereira-Filho et al., 2011) with a potential risk for OSA development. Li et al. (2002) determining that maxillomandibular advancement achieved expansion of the upper airway, and decreased the collapsibility of the airway showing that maxillary and mandible surgery is an important scheme to treat OSA. In other words, an important matter for respiratory and OSA patient analysis is a study of the craniofacial morphology and mandible position.

FCII and FCIII did not show differences in the nasopharynx space; based on this fact it could be assumed that differences of craniofacial morphology (sagittal class I, II or III facial deformity) do not need any modification in the nasopharinx area. However, the oropharynx and hypopharynx do show differences in the measurement and are related to mandible position.

Poor information is found in the literature working in comparisons between FCII and FCIII PAS. Degerliyurt et al. (2008) showed an interesting research and suggest that bimaxillary surgery can prevent narrowing of the upper airway in the correction of Class III deformities in comparison with mandibular setback surgery used as sole treatment. Hong et al. show the same results demonstrating that narrowing of the pharyngeal airway was smallerin patients undergoing bimaxillary surgery than in patients undergoing mandibular setback surgery. However, no study shows the relation between the smaller PAS and snoring or OSA. These facts can be related to multifactorial aetiology of OSA and for this reason no number or volume of the PAS could be associated with this pathology. On the other hand, a change in body posture has an effect on upper airway size owing to postural effects of the tongue (Pae, 1989), showing that the image type is an important element in this analysis. It can be concluded that differences exist between FCII and FCIII when the PAS is analyzed. New research is necessary to define this condition and its effect on the quality of life in this group of patients.

OLATE, S.; CANTIN, M.; VASQUEZ, B.; DEL SOL, M.; HENRIQUEZ-ALARCÓN, M. \& DE MORAES, M. Espacio de la vía aérea faríngea en sujetos con deformidad facial clase II y clase III. Int. J. Morphol., 32(4):1271-1276, 2014.

RESUMEN: Las deformidades faciales son asociadas a diferencias en la posición mandibular evidenciando diferencias en la relación maxilomandibular. El objetivo de esta investigación fue comparar el espacio aéreo faríngeo en sujetos con deformidad facial clase II y clase III. Se incluyeron 28 sujetos con características esqueletales asociadas a clase II o clase III seguidos de la evaluación del angulo SNA y el resalte dentario; se excluyeron los sujetos con asimetría fa- 
cial y otras deformidades faciales y sujetos con historia de trauma facial o historia de cirugía facial; se realizó la tomografía computadorizada cone beam para evaluar el área de nasofaringe, orofaringe, hipofaringe y la distancia entre la espina geni mandibular y el hueso hioides; los datos se analizaron con estadística descriptiva y la prueba t usando un valor de 0,05 para establecer significancia estadística. Se observó que los sujetos de clase II presentaron valores menores a los sujetos clase III en todas las mediciones realizadas; en el área de orofaringe e hipofaringe se observaron las diferencias mas importantes, estadísticamente significativas $(\mathrm{p}<0,05)$. Se puede concluir que los sujetos con deformidad facial clase II presentan un espacio de vía aérea faríngea más estrecho y se sugiere que este temática sea resuelta en la etapa de diagnóstico previo a la selección de tratamientos quirúrgicos o no quirúrgicos.

PALABRAS CLAVE: Deformidad facial; Vía área faríngea; Apnea obstructiva del sueño.

\section{REFERENCES}

Bradley, T. D. \& Floras, J. S. Sleep apnea and heart failure: Part I: obstructive sleep apnea. Circulation, 107(12):16718, 2003.

Degerliyurt, K.; Ueki, K.; Hashiba, Y.; Marukawa, K.; Nakagawa, K. \& Yamamoto, E. A comparative CT evaluation of pharyngeal airway changes in class III patients receiving bimaxillary surgery or mandibular setback surgery. Oral Surg. Oral Med. Oral Pathol. Oral Radiol. Endod., 105(4):495-502, 2008.

Hong, J. S.; Park, Y. H.; Kim, Y. J.; Hong, S. M. \& Oh, K. M. Three-dimensional changes in pharyngeal airway in skeletal class III patients undergoing orthognathic surgery. J. Oral Maxillofac. Surg., 69(11):e401-8, 2011.

Kitagawara, K.; Kobayashi, T.; Goto, H.; Yokobayashi, T.; Kitamura, N. \& Saito, C. Effects of mandibular setback surgery on oropharyngeal airway and arterial oxygen saturation. Int. J. Oral Maxillofac. Surg., 37(4):328-33, 2008 .

Lenza, M. G.; Lenza, M. M.; Dalstra, M.; Melsen, B. \& Cattaneo, P. M. An analysis of different approaches to the assessment of upper airway morphology: a CBCT study. Orthod. Craniofac. Res., 13(2):96-105, 2010.

Li, K. K.; Guilleminault, C.; Riley, R. W. \& Powell, N. B. Obstructive sleep apnea and maxillomandibular advancement: an assessment of airway changes using radiographic and nasopharyngoscopic examinations. $J$. Oral Maxillofac. Surg., 60(5):526-30, 2002.
Machado, A. J. \& Crespo, A. N. Cephalometric Evaluation of the Airway Space and Hyoid Bone in Children with Atypical Deglutition: Correlations Study. Int. J. Morphol., 30(1):341-6, 2012.

Mahowald, M. W.; Iber, C. \& Walsh, J. K. Evaluation of obstructive sleep apnea: Considerations and caveats. Oper. Tech. Otolaryngol. Head Neck Surg., 2(2):73-80, 1991.

Muñoz, G.; Olate, S.; Cantín, M.; Vásquez, B. \& Del Sol, M. TMJ in facial class III deformity. Condylar morphology relations. Int. J. Clin. Exp. Med., 7(9):3113-7, 2014a.

Muñoz, G.; Olate, S.; Cantín, M.; Vásquez, B.; Del Sol, M. \& Fariña, R. TMJ in facial class III deformity. Condyle/fossa relations. Int. J. Clin. Exp. Med., 7(9):2735-9, 2014b.

Olate, S.; Cantín, M.; Alister, J. P.; Uribe, F.; Navarro, P.; Olate, G. \& de Moraes, M. Relationship between condylar size and transverse facial asymmetry in subject with condylar hyperplasia. Int. J. Morphol., 31(3):937-41, 2013.

Olate, S.; Cantin, M.; Vasquez, B.; del Sol, M. \& de Moraes, M. Facial soft tissue in subjects with class II and class III facial deformities. Preliminary results. Int. J. Morphol., 32(3):1022-5, 2014

Pae, E. K. A comparative study of the relationship between airway size, tongue activity and body position. Master's Thesis. Vancouver, University of British Columbia, 1989.

Pereira-Filho, V. A.; Castro-Silva, L. M.; de Moraes, M.; Gabrielli, M. F.; Campos, J. A. \& Juergens, P. Cephalometric evaluation of pharyngeal airway space changes in class III patients undergoing orthognathic surgery. J. Oral Maxillofac. Surg., 69(11):e409-15, 2011.

Powell, N. B.; Riley, R. W. \& Guilleminault, C. Rationale and indications for surgical treatment in obstructive sleep apnea syndrome. Oper. Tech. Otolaryngol. Head Neck Surg., 2(2):87-90, 1991.

Saitoh, K. Long-term changes in pharyngeal airway morphology after mandibular setback surgery. Am. J. Orthod. Dentofacial Orthop., 125(5):556-61, 2004.

Saccucci, M.; D'Attilio, M.; Rodolfino, D.; Festa, F.; Polimeni, A. \& Tecco, S. Condylar volume and condylar area in class I, class II and class III young adult subjects. Head Face Med., 8:34, 2012.

Susarla, S. M.; Thomas, R. J.; Abramson, Z. R. \& Kaban, L. B. Biomechanics of the upper airway: Changing concepts in the pathogenesis of obstructive sleep apnea. Int. J. Oral Maxillofac. Surg., 39(12):1149-59, 2010. 
OLATE, S.; CANTIN, M.; VASQUEZ, B.; DEL SOL, M.; HENRIQUEZ-ALARCÓN, M. \& DE MORAES, M. Pharyngeal airway space in subjects with class II and class III facial deformities. Int. J. Morphol., 32(4):1271-1276, 2014.

Tkacova, R.; Rankin, F: Fitzgerald, F. S.; Floras, J. S. \& Bradley, T. D. Effects of continuous positive airway pressure on obstructive sleep apnea and left ventricular afterload in patients with heart failure. Circulation, 98(21):2269-75, 1998.

Watanabe, T.; Isono, S.; Tanaka, A.; Tanzawa, H. \& Nishino, T. Contribution of body habitus and craniofacial characteristics to segmental closing pressures of the passive pharynx in patients with sleep-disordered breathing. Am. J. Respir. Crit. Care Med., 165(2):260-5, 2002.

White, D. P. Pathogenesis of obstructive and central sleep apnea. Am. J. Respir. Crit. Care Med., 172(11):1363-70, 2005.
Correspondence to:

Prof. Dr. Sergio Olate

División de Cirugía Oral y Maxilofacial

Universidad de La Frontera

Claro Solar 115, Oficina 420

Temuco

CHILE

Email: sergio.olate@ufrontera.cl

Recibido : 16-03-2014

Aceptado: 22-08-2014 